Acta Horticulturae et Regiotecturae 1

Nitra, Slovaca Universitas Agriculturae Nitriae, 2016, pp. 13-16

\title{
HISTORICAL TERRAIN CHANGES MAPPING DUE TO THE WIND EROSION DEGRADATION PROCESSES
}

\author{
Lenka LACKÓOVÁ*1 , Jana KOZLOVSKY DUFKOVÁ \\ 'Slovak University of Agriculture in Nitra, Slovak Republic \\ ${ }^{2}$ Mendel University in Brno, Czech Republic
}

\begin{abstract}
In this paper we compare the Digital terrain model (DTM) created from contours extracted from the Base Map of Slovakia with the scale of $1: 10000$ from year 1970 and DTM derived from the points measured with the Trimble ${ }^{\oplus}$ R8 GPS receiver with TSC2 data loggers from 2013. The purpose of the provision of these DMTs is to create baseline information that we used in quantifying physical changes due to wind erosion processes in the terrain of selected field in 43 years, since 1970 to present 2013. The comparison of the DTMs was validated by the volumetric method during wind erosion event. The results achieved from the volumetric method show that in one erosion event, about $480 \mathrm{~m}^{3}$ of soil has been eroded and transported to another location. In DTM comparison (43 years) volume amount which was calculated by "3D analyst tool - terrain and TIN surface - Surface difference", $31,228 \mathrm{~m}^{3}$ of eroded soil was accumulated in the area and $16,236 \mathrm{~m}^{3}$ was lost from the area. Totally $14,922 \mathrm{~m}^{3}(5.5 \mathrm{~cm}$ height across the whole field) was transported from outlying eroded fields.
\end{abstract}

Keywords: Digital terrain model, wind erosion, historical terrain changes

Wind erosion is one of the main processes of agricultural soil degradation that affects about 549 million hectares globally (Šarapatka et al., 2002). Although it is a less significant degradation process in Slovakia, it potentially endangers about $6.2 \%$ of the land area, which represents about 150,000 hectares (Muchová and Vanek, 2009). Wind erosion occurs when the forces applied to the soil by wind are greater than the resistance of the soil to these forces (Dufková, 2007). The control and limitation of soil erosion in Slovakia is regulated by the Act 220/2004 (Collection of Laws on the Protection and Use of Agricultural Land) (Varga and Stred'anský, 2012) and the amending Act 245/2003 (Integrated Pollution Prevention and Control of the Environment) and certain other additional amendments (Jurík and Palšová, 2012). For wind erosion the limit is 15 tons per 1 ha per year. According to the Slovak Technical Standard STN 754501 (2000) Hydromelioration, erosion protection of agricultural land, the maximum allowable value for single soil erosion is 0.014 tons per hectare. The process of wind erosion causes damage to agricultural land, in particular by thinning the surface humus layer, by transported soil particles damaging young plant shoots (Urban, 2012) via the transport of agrochemicals, through the amassing of eroded particles which accumulate in communication systems, channels and windbreaks and that negatively affect the quality of surface water and the air (Pokrývková et al., 2012). Soil erosion may be accurately determined geographically (Kliment and Kliment, 2012). Digital elevation models allow investigating the influence of erosional processes on landscape form (Leimanová and Fuska, 2011). DTMs consist of a spatially registered set of elevation points that collectively describe a topographic surface. Data are organized as either a matrix of points that form a regular grid, or as the coordinates and elevation of points that define a triangulated irregular network (TIN). The choice of data sources and terrain data sampling techniques is critical for the quality of the resulting DTM (Al-Ruzouq and Rawashdeh, 2014). At present, most DTM data are derived from three alternative sources: ground surveys, photogrammetric data capture, or from digitized cartographic data sources (Weibel and Heller, 1991). Survey data tend to be very accurate and may be input directly into computer systems. However, as this particular data collection technique is relatively time consuming, its use is limited to small areas (Weibel and Heller, 1991). Contours are mainly a form of terrain visualization and are not particularly useful as a scheme for numerical surface representation; however, since large area coverage is achieved relatively cost effectively, digitized cartographic documents provide a compromise method of obtaining DMTs for use at medium and small scales.

\section{Material and methods}

\section{Description of the selected field}

Our research field is situated in the rural municipality of Močenok, Slovakia with the area of 27 ha. The Močenok regional area lies in the Danubian Lowland, on the southwestern border of the Nitra highlands, in the shallow valley of the Dlhy kanal River. The current structure of the country 
reflects man's use of the natural landscape (Húska and Tátošová, 2001). This area is characterized by the dominant soil type chernozem, which covers the northern, central and eastern part of the region (Varga and Halva, 2012). Firstly, we evaluated the soils in the field and identified a vulnerable soil type like black chernozem; easy drying, formed from non-carbonate aeolian sands with silicate humus, A horizon $\left(\mathrm{CaCO}_{3}\right.$ content $\left.<0.3 \%\right)$. In the horizon up to $100 \mathrm{~cm}$ from the surface with rust - brown stains caused by oxidation of $\mathrm{Fe}^{3+}$. Loam (moderate soil) $-79.35 \%$ - represents the largest area in terms of grain size, sandy loam (moderate soil) covers $17.56 \%$ and light loam (light soils) covers 1.93\% (Urban, 2013). The field has irregular shape similar to rectangle from 3 sides and rhomboid from one side. The rhomboid side is lined by melioration channel followed by windbreak with the length of $300 \mathrm{~m}$ from the north side. In the middle of the field there is situated another windbreak with the length of $130 \mathrm{~m}$.

\section{Derivation of DTMs}

Two Digital Terrain Models were derived covering the 27 ha of field under investigation. The historic DTM was entirely derived from contour lines taken from the Base Map of Slovakia with the scale $1: 10000$ from the year 1970. The supplementary contour line interval is $0.5 \mathrm{~m}$ and the intermediate interval is $1 \mathrm{~m}$. To convert contours from the Base Map of Slovakia we used automatic vectorization tool in ArcMap10. GPS data used to derive the present DTM were measured with Trimble ${ }^{\circledR}$ R8 GPS receiver with TSC2 data loggers. We used two methods to measure these points with corrections on real time (RTK) method with Virtual Reference Stations (VRS) and Differential GPS method with post processing. The accuracy required for the ground control points was in the range of $<0.1 \mathrm{~m}$ in $X$, $Y$, and $Z$. The cell size or spatial resolution of the final raster DTM was $1 \mathrm{~m}$. This size of cell is adequate to represent the objects of interest since it is smaller than the mean size of features on the terrain. GIS software is capable of making this comparison for the area simultaneously, through raster algebra of pixel values.

\section{Results and discussion}

\section{DTM processing}

In order to construct a comprehensive DTM it is necessary to establish the topological relations between the data elements as well as an interpolation model to approximate the surface behavior. The overwhelming majority of DTMs conform to one or other of two data structures: raster (Multiquadratic Radial Basis Function) or TIN (Triangulated Irregular Network). The raster uses a model to fit surface to the known, irregularly spaced elevation points (Hardy, 1990; Buhman, 2003). As TIN interpolation works the best for creating digital topography from irregularly space known elevation points, like points extracted from contours, we chose TIN as a tool to create DTM model for both contours and measured points. In ArcMap 10 we used "3D analyst tool - TIN management - create TIN". TIN structures are based on triangular elements, with vertices at the sample points (Figure 1). TINs are able to reflect adequately the variable density of data points and the roughness of terrain.

Within GIS, digital terrain models are most valuable as bases for the extraction of terrain-related attributes and features. Information may be extracted in two ways: by visual analysis of graphic representation or by quantitative analysis of digital terrain data. Interpretation procedures, along with visualization functions, thus represent an important objective of GIS related terrain modeling. For each $1 \times 1 \mathrm{~m}^{2}$ on the ground, the value of height of the historic DTM is subtracted from the value of the recent DTM height. This step was performed within 3D analyst tool "Terrain and TIN surface - Surface difference". This tool calculates the volumetric difference between two triangulated irregular networks (TIN), or terrain datasets. As the result of this operation, another raster dataset is derived, called the DTM change map, which is shown in Figure 2. In this map, positive values represent a gain in height or accretion and negative values represent erosion or loss of height.

In the total 15.7 ha of the selected field gained in height or accretion and 10.7 ha represent erosion or loss of height.

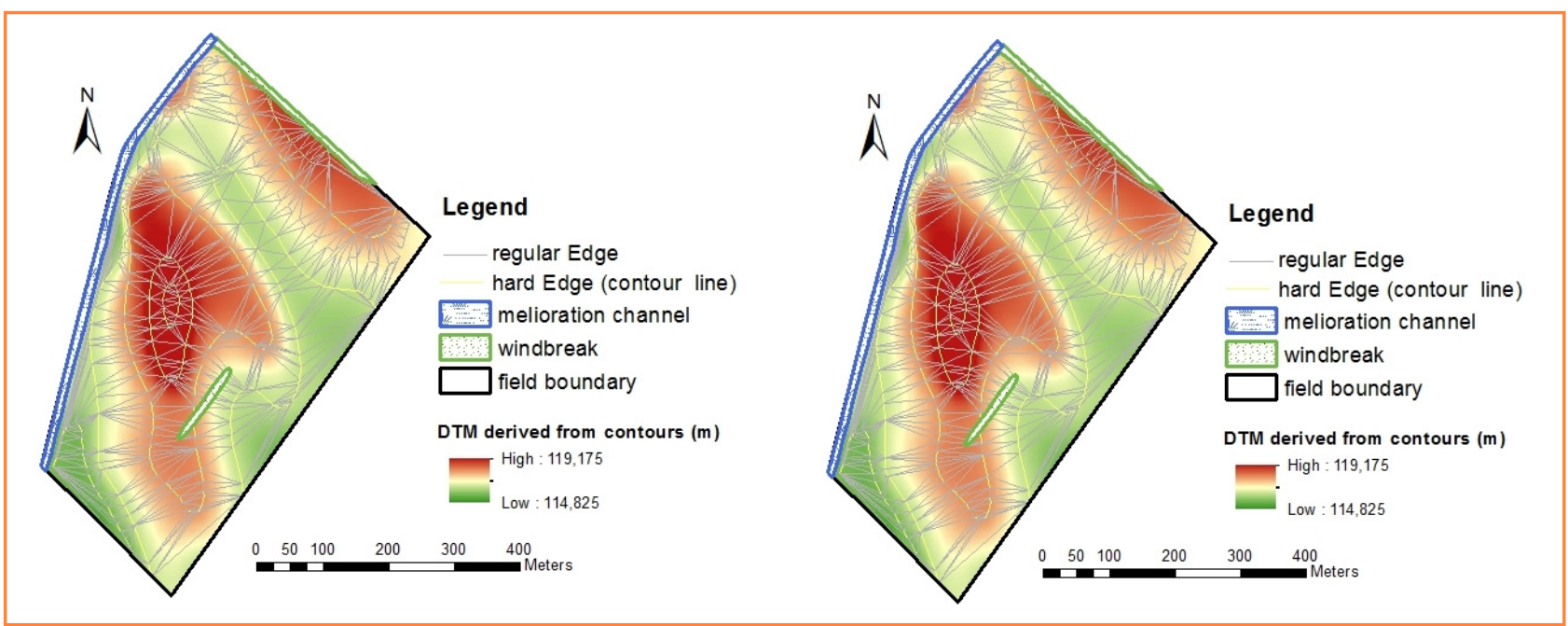

Figure 1 TIN models: left side derived from contours, right side derived from measured points 


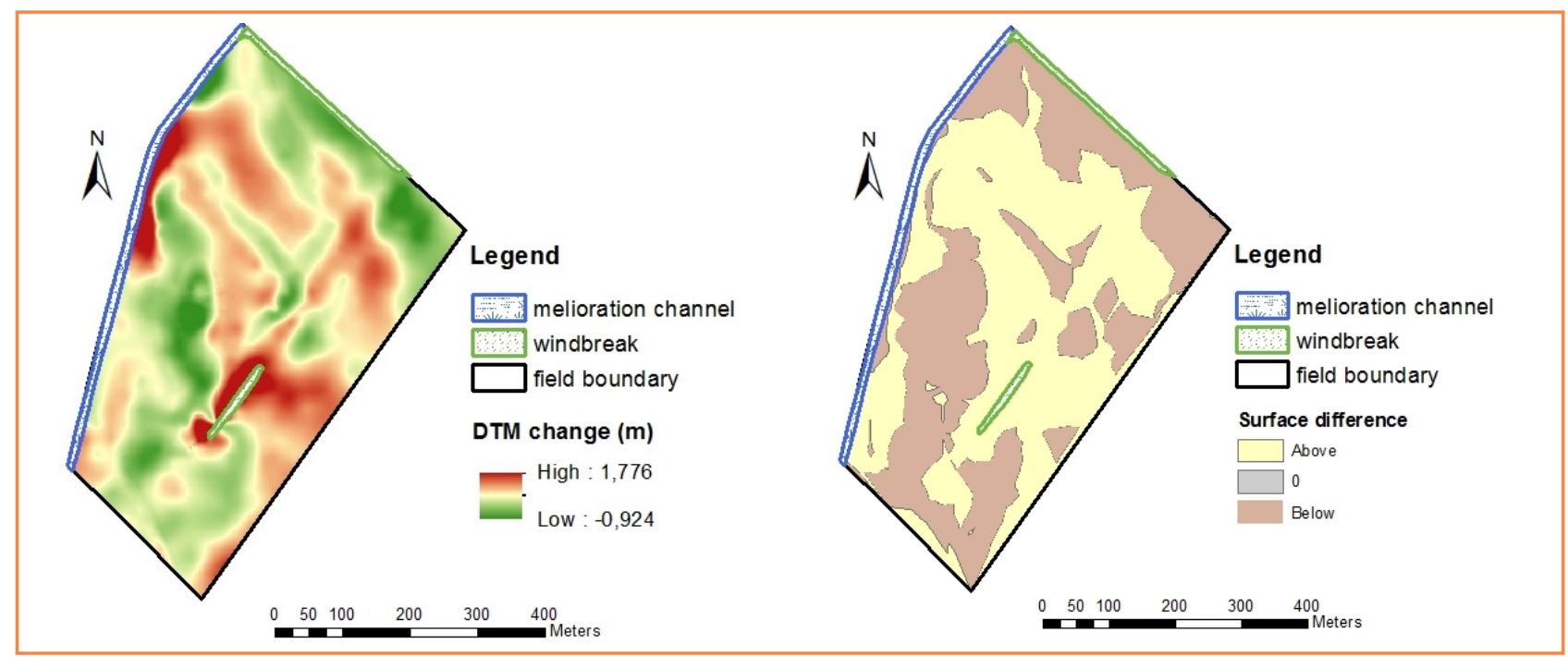

Figure 2 Digital terrain model change map of selected field

The rest 0.6 ha remain with no change. In volume amount which was calculated by "3D analyst tool - terrain and TIN surface - Surface difference", 31,228 $\mathrm{m}^{3}$ of eroded soil was accumulated in the area and $16,236 \mathrm{~m}^{3}$ was lost from the area. Totally, $14,922 \mathrm{~m}^{3}$ (5.5 cm height across the whole field) was transported from outlying eroded fields which is mainly seen around the windbreak area (Figure 3). The problem with the Base Map of Slovakia is that the mean error in the determination of the transformation key is 1.03 meters, with a variance of $0.29 \mathrm{~m}$ with a probability of $95 \%$, it is $0.10 \mathrm{~mm}$ in the map scale, which corresponds to the accuracy of cartographic printing materials processing analogue maps. This ultimately means that vectorization of printing materials analogue maps was reduced the accuracy of $1 \mathrm{~m}$. In our areas there were identified two geodetic points which were validated and based on the validation we expect the error to be minimized.

We verified the intensity of wind erosion for one wind erosion event by the volumetric method, which is based on direct surveys of soil deposition volumes and deposition of accumulated soil. The volume is calculated by measuring the transverse profiles and lengths of accumulated products of erosion activity. The volume of accumulated soil and

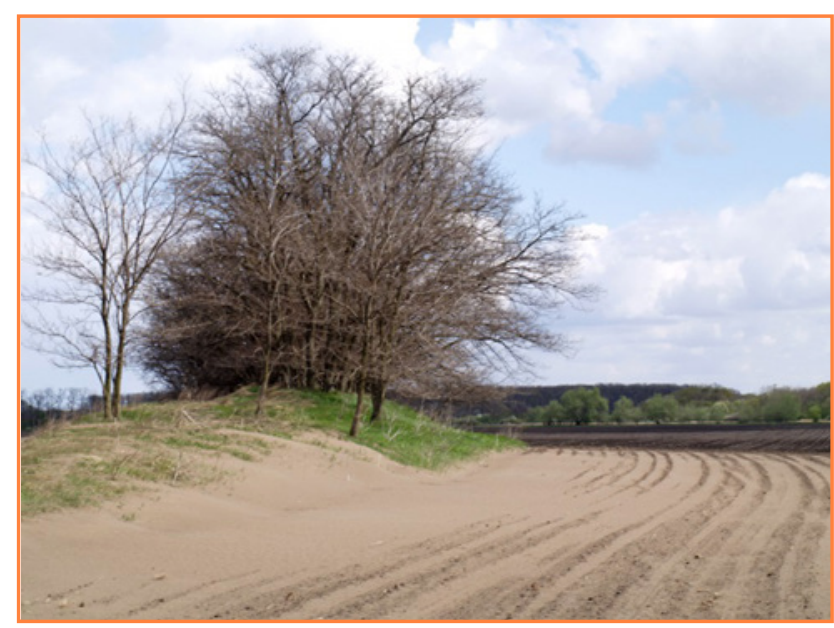

Figure 3
Volume of wind silts around windbreak deposits that were created in front of the windbreaks and caught internally in a ditch at the interface between plots and on the nearby field where corn was planted was calculated by the volumetric method (Urban et al., 2013).

The sum of all deposits and soil accumulation represents a volume of $485.3 \mathrm{~m}^{3}$ of accumulated soil that has been
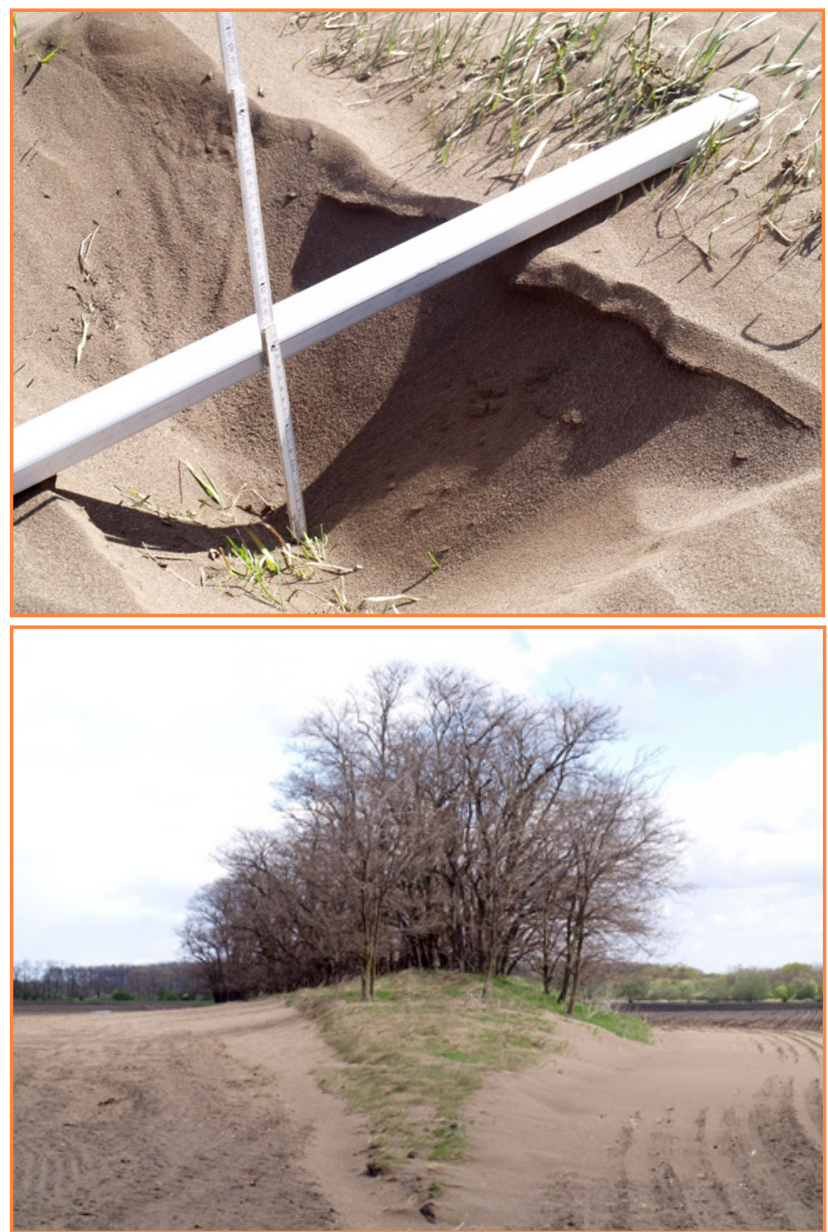

Figure 4 Height of soil accumulation in windbreak measurement 
Table 1 Calculated volumes of soil accumulation in one erosion event

\begin{tabular}{|l|c|c|c|}
\hline Place of soil accumulation & Transverse profile content in $\mathbf{~}^{\mathbf{2}}$ & Length $\mathbf{~} \mathbf{~} \mathbf{~}$ & Calculated volume in $\mathbf{~}^{\mathbf{3}}$ \\
\hline In front of windbreak & 0.38 & 130 & 49.4 \\
\hline Windbreak & 1.35 & 130 & 175.5 \\
\hline Ditch between two fields & 0.12 & 160 & 19.2 \\
\hline Accumulation between rows & 1.51 (total 180) & 160 & 241.2 \\
\hline Total & - & - & 485.3 \\
\hline
\end{tabular}

eroded and transported to another location during one erosion event. By the density of $1.1 \mathrm{~g} \mathrm{~cm}^{-3}$ ( $60 \%$ porosity), the weight of eroded material is 533.8 tons, which represents soil loss of $63.5 \mathrm{t} \mathrm{ha}^{-1}$

\section{Conclusion}

Digital terrain models allow historical investigation of the influence of erosion processes on landscape form and analyses of soil movements within wind erosion degradation processes. As the result of the application of the DTMs subtraction for identification of change in the landscape, a map showing erosion and accretion in different quantities across the whole field studied in 43 years was produced. The result of the interpretation of DTM changes due to wind erosion degradation processes can be used as an input for further environmental protection planning, soil erosion potential methods, ground consolidations and many other applications. Although the models have been validated and can be said to be quite accurate, neither of them is a perfect replica of the terrain. Each of them represents the state of the ground in a moment in time and both have certain inaccuracies.

\section{Acknowledgment}

This paper was published with financial support VEGA 2/0054/14 Vplyv biologického pôdneho povlaku a mikrotopografie na infiltráciu a prúdenie vody v piesočnatej pôde.

\section{References}

ACT 220/2004 (Collection of Laws on the Protection and Use of Agricultural Land) on the protection and use of agricultural soil.

BUHMANN, M.D. 2003. Radial Basis Functions: Theory and Implementations. Cambridge : Published by Cambridge University Press, 2003. 259 p. ISBN 0521633389, 9780521633383.

DUFKOVÁ, 2007. Comparison of potential and real erodibility of soil by wind. In Acta Universitatis Agriculturae et Silviculturae Mendelianae Brunensis, vol. 55, 2007, no. 4, p. 15-21. ISSN 1211-8516.

HARDY, R.L. 1990. Theory and applications of the multiquadric biharmonic method, Computers and mathematics with applications. 1990, no. 19, pp. 163-208.
HÚSKA, D. - TÁTOŠOVÁ, L. 2001. Úloha polnohospodárskej krajiny z hladiska manažmentu životného prostredia. In K aktuálnym otázkam v PPoK pri vstupe do tretieho tisicročia. Nitra : SPU, 2001.

JURÍK, L. - PALŠOVÁ, L. 2012. Legislatíva ochrany životného prostredia. Nitra : SPU, 2012. 138 s. ISBN 978-80-552-0906-7.

KLIMENT, T. - KLIMENT, M. 2012. Environmentalne geopriestorove informacie ziskane v prostredi "mainstream" webu. In Krajinné inžinierstvo - trendy a perspektivy. Nitra : SPU, 2012.

MUCHOVÁ, Z. - VANEK, J. 2009. Metodické štandardy projektovania pozemkových úprav. SPU $v$ spolupráci s Ministerstvom pôdohospodárstva, Nitra, 2009.

POKRÝVKOVÁ, J. - FUSKA, J. - BÁREK, V. - LENÁRT, R. 2012. Agricultural crops reduction caused by imission load of the habitat. In International Scientific Publications, Ecol. Safety, vol. 6, 2012, no. 2, pp. 71-80.

AL-RUZOUQ, R. - RAWASHDEH, S. 2014. Geomatics for Rehabilitation of Mining Area in Mahis, Jordan. In Journal of Geographic Information System, 2014, no. 6, 123-134. DOI:10.4236/ jgis.2014.62014.

STN 754501.2000 . Hydromelioration. Conservation of agricultural soils. Basic regulations.

ŠARAPATKA, B. - DLAPA, P. - BEDRNA, Z. 2002. Kvalita a degradace půdy. Olomouc : Univerzita Palackého, 2002. 250 s. ISBN 80-244-0584-9.

URBAN, T. et al. 2013. Wind erosion in the agricultural landscape. The wind erosion equation used in GIS. A monograph. Krakow : Wydawnictwo Uniwersytetu Rolniczego, 2013. ISBN 978-83-60633-97-7

URBAN, T. 2012. Stanovanie intenzity veternej erózie pomocou matematického modelu - rovnice WEQ upravenej pre podmienky Slovenska v katastrálnom území Močenok. Dizertačná práca. Nitra : SPU, 2012.

VARGA, V. - HALVA, J. 2012. Modelovanie optimálneho rozmiestnenia protieróznych opatrení v území. In Študentská vedecká konferencia FZKI 2012. Nitra : SPU, 2012. ISBN 978-80_552-0888-6.

VARGA, V. - STREĎANSKÝ, J. 2012. Vplyv zmeny limitnej hodnoty odnosu pôdy v novele Zákona 220/2004 na výmeru ohrozenej pôdy veternou eróziou pre vybrané katastrálne územie Sekule. In Krajinné inžinierstvo - trendy a perspektívy. Nitra : SPU, 2012. ISBN 978-80-552-0961-6

WEIBEL, R. - HELLER, M. 1991. Digital Terrain Modeling. In Maguire, D.J. - Goodchild, M.F. - Rhind, D.W. (eds.). Geographical Information Systems: Principles and Applications. London : Longman, 1991. pp. 269-297. 